\title{
PEMODELAN KASUS DBD DI PROVINSI JAWA TIMUR DENGAN METODE DATA PANEL
}

\section{MODELLING OF DHF CASES IN EAST JAVA WITH PANEL DATA METHOD}

\author{
Annisa Dwinda Shafira \\ Departemen Biostatistika dan Kependudukan \\ Fakultas Kesehatan Masyarakat Universitas Airlangga \\ Jl. Mulyorejo Kampus C Unair Surabaya, Jawa Timur 60115, Indonesia \\ Alamat korespondensi: Annisa Dwinda Shafira \\ E-mail: annisa.dwinda.afira-2015@fkm.unair.ac.id
}

\begin{abstract}
The combination of panel data regression consist of time series data, it was collected based on a characteristic at a certain time (cross section). This research aimed to analyze the affecting factors and dominant factors of Dengue Hemoragic Fever (DHF) cases in East Java using panel data regression. This research uses secondary data published by the East Java Provincial Health Office, namely the Health Profile and the East Java Provincial Statistics Agency such as documents of each Districts/City in Numbers of East Java on 2014-2017 using total research population that were collected in all districts/cities in East Java Province. The data of new cases of DHF and factors affecting the incidence of DHF including clean and healthy living behavior in the household, poverty, population density, rainfall in East Java on 2014-2017. Panel regression analysis is used to determine the best model of the CEM, FEM and REM using Chow test, Hausman test and Langrange Multiplier test. Based on the results, the best model of panel regression is FEM with affecting variables such as poverty, population density, and rainfall.
\end{abstract}

Keywords: panel regression, dengue hemoragic fever, fixed effect model

\begin{abstract}
ABSTRAK
Pengkombinasian regresi data panel terdiri antar runtutan data berdasarkan waktu (time series) dan data yang dikumpulkan berdasarkan suatu karakteristik pada satu waktu tertentu (cross section). Tujuan dilakukan untuk menganalisis faktor yang berpengaruh terhadap kejadian Demam Berdarah Dengue (DBD) dengan menggunakan regresi data panel. Penelitian menggunakan data sekunder dipublikasi oleh Dinas Kesehatan Provinsi Jawa Timur yaitu Profil Kesehatan dan Badan Pusat Statistik Provinsi Jawa Timur berupa dokumen Kabupaten/Kota dalam Angka di Jawa Timur tahun 2014-2017 dengan sampel yaitu total populasi penelitian yaitu 38 kabupaten/kota. Data yang dianalisis adalah kasus baru DBD dan faktor yang mempengaruhi kejadian DBD meliputi perilaku hidup, bersih dan sehat (PHBS) di rumah tangga, kemiskinan, kepadatan penduduk, curah hujan. Analisis regresi panel yang digunakan untuk menentukan model terbaik dari FEM, CEM dan REM dengan menggunakan Chow test, Hausman test dan Langrange Multiplier test. Berdasarkan hasil penelitian ini model terbaik dari regresi panel adalah FEM dengan variabel yang berpengaruh yaitu kemiskinan, kepadatan penduduk, dan curah hujan.
\end{abstract}

Kata kunci: regresi data panel, demam berdarah dengue, fixed effect model

\section{PENDAHULUAN}

Statistika yang sering digunakan di bidang kesehatan tidak terkecuali adalah regresi. Regresi merupakan teknik pemodelan dalam sebuah hubungan antara dependent variable (variabel respons) dan satu atau lebih independent variable lainnya (variabel prediktor) (Yan \& Su, 2009). Analisis regresi digunakan untuk mengestimasi dan penduga dimasa yang akan datang pada 
korelasi antar variabel independent dan dependent. Analisis juga digunakan untuk melihat bentuk hubungan antar dua data tersebut.

Penggabungan pada regresi panel menggunakan gabungan antar data runtunan waktu (time series) dan potong lintang (cross section). Runtunan waktu pada regresi panel diperoleh dengan mengamati karakteristik dari sejumlah $n$ unit analisis (cross section) pada waktu yang sama (dalam harian, bulanan, kuartalan, atau tahunan). Hal tersebut menunjukkan bahwa regresi tersebut memiliki dimensi ruang dan waktu (Gujarati, 2008).

Pengkombinasian antara data runtutan waktu dan potong lintang dapat meningkatkan kualitas serta kuantitas data menjadi optimal. Menurut Pangestika \& Widodo (2017), apabila penggabungan data tersebut dilakukan, maka akan menjadi pool data dalam membuat sebuah model regresi, sehingga hasil akan menjadi lebih baik daripada menggunakan cross section atau time series saja. Selain itu, derajat bebas yang besar akan dihasilkan dari penggabungan data silang dan runtutan waktu sehingga hasil analisis statistik lebih baik. Penghilangan variabel yang bermasalah juga merupakan kelebihan dari penggabungan kedua data tersebut (Sriyana, 2014).

Flavivirus adalah genus dari penyakit Demam Berdarah Dengue (DBD). Vektor yang ada di Indonesia yang paling utama dan terdapat di seluruh pelosok adalah Aedes aegypti. Kasus DBD selalu datang pada waktu yang tak menentu dan penderitanya pada semua golongan umur.

Penyakit DBD memiliki ketergantungan pada penyakit DBD di daerah lain yang berdekatan karena dapat menyebar secara langsung melalui ruang dan waktu oleh gigitan nyamuk dari orang yang sudah tergigit ke orang lain dan dari tempat satu ke tempat lain. Apabila suatu wilayah menjadi endemi DBD maka akan berpotensi menyebar pada wilayah baru yang lokasinya dekat dengan endemic tersebut (Tomia et al., 2016). Metode analisis yang tepat adalah menggunakan model data panel spasial karena menggunakan penggabungan data antar wilayah dan beberapa waktu maka yang diamati pada tiap wilayah dalam kurun waktu tertentu. Harapannya dengan analisis data panel spasial dapat menghasilkan model yang lebih baik. Hal tersebut karena adanya pengaruh data antar waktu yang diamati dengan hubungan spasial antar wilayah pengamatan (Diputra, Sadik dan Angraini, 2012).

Diketahui Jawa Timur memiliki incident rate dengan satuan per 100.000 penduduk kejadian DBD. Tahun 2014 sebesar 24 yang masih memenuhi target Renstra sebesar 52. Tahun 2015 dan 2016 naik secara signifikan. Tahun 2015 menjadi 54 dan tahun 2016 sebesar 64,8 sehingga tidak memenuhi target sebesar 49. Namun pada tahun 2017 angka kesakitan mengalami penurunan sebesar 20 dengan target 49 .

Berdasarkan tren incident rate DBD tersebut, maka perlu diketahui apa saja yang mempengaruhi kejadian DBD berdasarkan faktor yang diketahui. Analisis regresi data panel menggunakan potong lintang dan runtutan waktu, maka data potong lintang yang digunakan adalah angka insiden dan faktor yang diduga mempengaruhi jumlah kasus DBD. Sedangkan data runtutan waktu adalah objek yang diukur selama periode 2014 hingga 2017.

Faktor pengaruh dari tingginya angka kejadian kasus DBD tersebut dapat dibuat dengan model segitiga epidemiologi (epidemiologic triad/triangle). Segitiga tersebut terdiri dari agent/bibit penyakit, host/penjamu, dan environment/lingkungan. Penyakit DBD termasuk dalam golongan penyakit menular dipengaruhi oleh ketiga faktor tersebut. Host/penjamu dalam mempengaruhi terjadinya penyakit DBD. Menurut Ang, Rohani dan Look (2010), kemiskinan secara tidak langsung mempengaruhi kesediaan kelayakan rumah sehingga mendukung perkembangbiakan nyamuk, sehingga penduduk miskin mudah terpapar atau berisiko. Penelitian yang dilakukan di Kabupaten Minahasa Utara tentang penanggulangan DBD yang efektif oleh Tairas \& Posangi (2015) dengan variabel upaya pemberantasan sarang nyamuk dengan menerapkan 3M Plus (Menguras, menyikat TPA disertai Menutup TPA, dan Memanfaatkan kembali barang yang tidak digunakan) yang merupakan salah satu indikator PHBS.

Faktor selanjutnya adalah environment/ lingkungan yang meliputi kepadatan penduduk dan curah hujan. Daerah dengan jumlah kejadian 
DBD yang meningkat terdapat kaitannya dengan daerah yang padat penduduk. Hal ini dikarenakan terdapat hubungan dengan jarak terbang nyamuk. Curah hujan rendah dan berlangsung lama akan mempengaruhi kelangsungan hidup nyamuk Aedes aegypti dan akan menambah jumlah tempat berkembangnya nyamuk.

Penelitian ini memiliki tujuan untuk membuat model dari regresi panel dan mengetahui faktor yang mempengaruhi terjadinya kasus DBD di Jawa Timur tahun 2014-2017. Faktor yang diduga berkontribusi dalam kejadian DBD antara lain kemiskinan, PHBS di rumah tangga, kepadatan penduduk, dan curah hujan.

\section{METODE PENELITIAN}

Jenis penelitian menggunakan analitik bersifat non-reaktif yang merupakan pendekatan penelitian subjek tidak merasa sedang diteliti. Populasi penelitian adalah seluruh kabupaten/ sampel di Provinsi Jawa Timur. Sampel menggunakan total populasi wilayah dengan unit analisis 29 kabupaten dan 9 kota. Data diperoleh dari publikasi oleh Dinas Kesehatan Provinsi Jawa Timur dan Badan Pusat Statistik Provinsi Jawa Timur. Variabel dependen penelitian ini adalah angka kejadian DBD dan variabel independen adalah kemiskinan $\left(\mathrm{X}_{1}\right)$, PHBS pada rumah tangga $\left(\mathrm{X}_{2}\right)$, kepadatan penduduk $\left(\mathrm{X}_{3}\right)$ dan curah hujan $\left(\mathrm{X}_{4}\right)$.

Analisis penelitian menggunakan deskriptif dan inferensial. Analisis deskriptif dilakukan dengan menggambarkan kasus penyakit DBD dan faktor yang mempengaruhinya. Aplikasi STATA untuk mengaplikasikan regresi data panel. Tahapan yang dilakukan setelah variabel dependen dan independen diinput, kemudian dilakukan permodelan regresi data panel yang meliputi random effect model (REM), fixed effect model (FEM) dan common effect model (CEM).

Setelah permodelan terbentuk dilakukan estimasi uji untuk menentukan model terbaik diantara ketiganya menggunakan uji chow, uji langrange multiplier dan hausman. Kemudian dilanjutkan pengasumsian regresi yang meliputi autokorelasi, normalitas, dan heterokedesitisitas serta multikolinieritas. Apabila terjadi pelanggaran pada uji asumsi regresi, maka dilakukan transformasi dan kemudian akan dilakukan pengujian ulang pada regresi data panel. Kemudian menginterpretasi hasil dari regresi panel.

\section{HASIL PENELITIAN}

\section{Analisis Deskriptif}

Analisis deskriptif menunjukkan angka kejadian penyakit DBD tidak selalu mengalami kenaikan disetiap tahunnya, namun mengalami kenaikan yang cukup signifikan dari tahun 20142016 dan penurunan pada tahun 2017. Angka kejadian penyakit DBD pada tahun 2014 hingga 2017 berturut-turut dengan satuan per 100.000 penduduk sebesar $24 ; 54 ; 64 ; 20$.

Incident rate atau angka kejadian kasus DBD dengan satuan per 100.000 penduduk di Jawa Timur tertinggi pada tahun 2014 hingga tahun 2017 adalah pada Kota Probolinggo sebesar 140 pada tahun 2014, tahun 2015 dan 2016 pada Kabupaten Pacitan sebesar 300 dan 242 per 1000 penduduk, Kota Blitar sebesar 199 pada tahun 2017. Sedangkan angka kejadian terendah tahun 2014 terdapat pada Kabupaten Mojokerto sebesar 4, pada tahun 2015 sebesar 10 pada Kabupaten Mojokerto, tahun 2016 sebesar 17 kasus di Kabupaten Tuban dan tahun 2017 sebesar 7.

Grafik persentase variabel independen yang berpengaruh dalam kejadian DBD di Jawa Timur di Tabel 1. Tergambarkan pada Tabel 1 yaitu jumlah curah hujan $\left(\mathrm{X}_{4}\right)$ mengalami kenaikan dan penurunan dari $1722 \mathrm{~mm}$ menjadi $1592 \mathrm{~mm}$

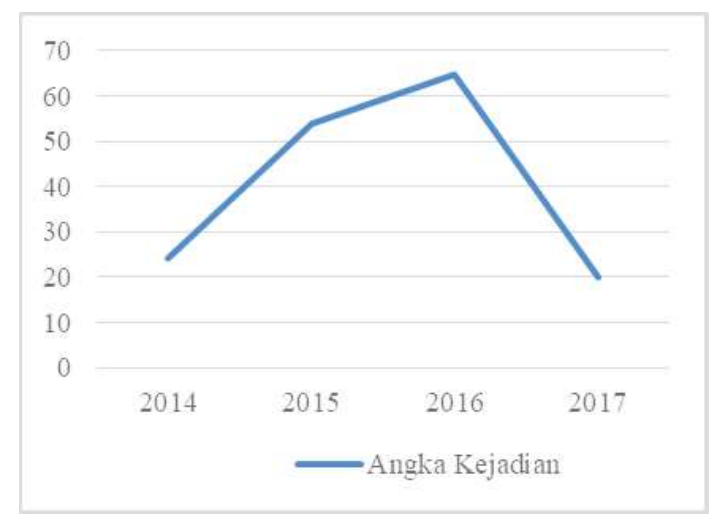

Gambar 1. Grafik Angka Kejadian DBD di Tahun 2014-2017. 
Tabel 1. Deskripsi Variabel Independen yang Berpengaruh pada Kejadian DBD di Provinsi Jawa Timur 2014-2017

\begin{tabular}{ccccc}
\hline Tahun & \% Kemiskinan & \% PHBS & $\begin{array}{r}\text { Kepadatan Penduduk } \\
\left(\mathbf{p e r} \mathbf{~ k m}^{2}\right)\end{array}$ & $\begin{array}{c}\text { Curah Hujan } \\
(\mathbf{m m})\end{array}$ \\
\hline 2014 & 12,09 & 46,28 & 1893,157 & 1722,18 \\
2015 & 12,16 & 48,63 & 1906,113 & 1592,51 \\
2016 & 11,87 & 49,63 & 1926,878 & 2445,60 \\
2017 & 11,62 & 54,0 & 1938,868 & 2007,28 \\
\hline
\end{tabular}

pada tahun 2015 kemudian mengalami kenaikan yang cukup tajam menjadi $2445 \mathrm{~mm}$ pada tahun 2016. Jumlah curah hujan tahun 2017 mengalami penurunan menjadi $2007 \mathrm{~mm}$ dari tahun 2016.

Variabel independen yang lain adalah kepadatan penduduk, PHBS di rumah tangga dan kemiskinan. Kenaikan terjadi pada jumlah kepadatan penduduk dan PHBS di rumah tangga, namun pada presentase kemiskinan mengalami penurunan pada setiap tahunnya.

\section{Analisis Regresi Panel}

\section{Uji Langrange Multiplier}

Penentuan random effect dan common effect ditentukan oleh langrange multiplier test. Random effect akan dipilih apabila terjadi penolakan pada $\mathrm{H}_{0}$. Berdasarkan analisis uji langrange multiplier menunjukkan probability 0,000 maka disimpulkan $\mathrm{H}_{0}$ ditolak. Model terpilih dari keduanya yaitu REM.

\section{Uji Chow}

Penentuan model terbaik dalam REM dan FEM adalah menggunakan uji chow. Apabila hipotesis menyatakan $\mathrm{H}_{0}$ ditolak, maka analisis chow test berdasarkan model terbaik yang dipilih yaitu FEM. Nilai signifikan dari uji chow sebesar 0,000 . Sehingga model yang diambil adalah FEM.

\section{Uji Hausman}

Model terbaik dari uji chow dan uji langrange multiplier masing-masing adalah REM bersamaan dengan FEM. Uji hausman menentukan yang terbaik dari keduanya. Apabila dalam $\mathrm{H}_{0}$ ditolak maka yang terpilih dari uji hausman adalah FEM. Uji hausman dalam
Tabel 2. Uji Signifikansi Tiap Variabel dengan FEM

\begin{tabular}{lc}
\hline \multicolumn{1}{c}{ Variabel } & $\boldsymbol{p}$ \\
\hline Curah Hujan & 0,000 \\
PHBS & 0,374 \\
Kepadatan Penduduk & 0,002 \\
Kemiskinan & 0,015 \\
Konstanta & 0,000 \\
\hline
\end{tabular}

penelitian ini memiliki probabilitas sebesar 0,0018 . Sehingga model yang didapatkan adalah FEM.

Setelah ditemukan FEM sebagai model terbaik, maka dilanjutkan analisis regresi panel. Tabel 2 diketahui nilai $p$ pada tiap-tiap variabel yang mempengaruhi jumlah kejadian penyakit DBD. Variabel yang memiliki nilai $p$ kurang dari dari $\alpha(0,05) \mathrm{H}_{0}$ tidak diterima dan dinyatakan sebagai faktor yang berpengaruh dalam kejadian penyakit DBD. Hasil dari analisis regresi panel, variabel yang berpengaruh adalah kemiskinan, curah hujan, dan kepadatan penduduk.

\section{Uji Asumsi Klasik}

Pengujian asumsi dalam data panel yang dilakukan meliputi normalitas, multikolinieritas, autokorelasi, dan heterokedastisitas.

\section{Uji Normalitas}

Shapiro wilk digunakan untuk menguji asumsi normalitas. Apabila hasil hipotesis yang dinyatakan $\mathrm{H}_{0}$ ditolak maka dinyatakan distribusi residual tidak normal. Nilai probabilitas dari uji normalitas dalam penelitian ini sebesar 0,000 maka dinyatakan distribusi residual tidak normal maka asumsi normalitas tidak memenuhi. 


\section{Autokorelasi}

Cara mendeteksi adanya korelasi variabel pada model prediksi dengan perubahan waktu yaitu menggunakan uji autokorelasi. Penelitian dilakukan menggunakan uji wooldridge untuk menguji autokorelasi. Apabila hipotesis pada uji wooldridge $\mathrm{H}_{0}$ tidak diterima maka terjadi autokorelasi. Hasil uji autokorelasi memiliki nilai probabilitas sebesar 0,4348 . Maka $\mathrm{H}_{0}$ diterima sehingga tidak terjadi autokorelasi dan memenuhi asumsi autokorelasi.

\section{Heteroskedastisitas}

Mendeteksi adanya heterokedastisitas dengan menggunakan uji wald test. Heteroskedastisitas terjadi apabila nilai probabilitas pada uji wald test yang digunakan memiliki nilai probabilitas kurang dari $\alpha(0,05)$. Hasil dari uji wald Test memiliki $p=0,000$ sehingga terjadi heteroskedasitas.

\section{Multikolinieritas}

Multikolinieritas untuk melihat adanya hubungan yang kuat antara independen. Asumsi multikolinieritas tidak terpenuhi apabila pada VIF lebih dari 10. Hasil asumsi multikolinieritas ditunjukkan pada Tabel 3, setiap variabel didalam penelitian ini tidak memiliki VIF lebih dari 10, maka asumsi multikolinieritas terpenuhi.

Tabel 3. Uji Multikolinieritas

\begin{tabular}{ll}
\hline \multicolumn{1}{c}{ Variabel } & VIF \\
\hline $\mathrm{X}_{1}$ (Kemiskinan) & 6,54 \\
$\mathrm{X}_{2}$ (PHBS di Rumah Tangga) & 9,10 \\
$\mathrm{X}_{3}$ (Kepadatan Penduduk) & 2,37 \\
$\mathrm{X}_{4}$ (Curah Hujan) & 7,69 \\
\hline
\end{tabular}

Tabel 4. Uji Signifikansi Setelah Penanganan Menggunakan Robust

\begin{tabular}{lcc}
\hline \multicolumn{1}{c}{ Variabel } & $\boldsymbol{p}$ & Koefisien \\
\hline Kemiskinan $\left(\mathrm{X}_{1}\right)$ & 0,022 & 20,73762 \\
Kepadatan Penduduk $\left(\mathrm{X}_{3}\right)$ & 0,001 & 0,2273604 \\
Curah Hujan $\left(\mathrm{X}_{4}\right)$ & 0,000 & 0,0401865 \\
\hline Konstanta & 0,000 & $-694,5028$ \\
\hline
\end{tabular}

\section{Penanganan Normalitas dan Heteroskedasitas}

Berdasarkan hasil penelitian ini, asumsi normalitas dan heterokedastisitas tidak memenuhi sehingga perlu penanganan khusus untuk asumsi keduanya. Mengatasi asumsi yang melanggar normalitas dan heterokedastisitas ini menggunakan robust. Tabel 4 merupakan hasil penanganan normalitas dan heterokedastisitas dengan menggunakan robust.

\section{Model Regresi Panel}

Model regresi terbaik yang sudah diuji melalui uji hausman adalah FEM. Hasil akhir dari regresi panel yang dilakukan melalui uji asumsi klasik dan penanganan robust sehingga didapatkan hasil pada Tabel 4. Berdasarkan tabel tersebut didapatkan model umum regresi data panel sebagai berikut:

$$
\begin{aligned}
\hat{y}_{i t}= & -694,5028+20,73762 X_{1 i t} \\
& +0,2273762 X_{3 i t}+0,0401865 X_{4 i t}
\end{aligned}
$$

$i$ adalah indeks tiap wilayah dan $t$ sebagai indeks waktu ke- $t$ dalam tahunan. Berdasarkan model regresi panel menyatakan apabila terjadi peningkatan pada kemiskinan $\left(\mathrm{X}_{1}\right)$ sebesar 0,2073762 disertai adanya peningkatan angka kepadatan penduduk $\left(\mathrm{X}_{3}\right)$ sebesar 0,227376 dan jumlah curah hujan $\left(\mathrm{X}_{4}\right)$ sebesar 0,0401865 akan mempengaruhi angka kejadian kasus DBD.

Model terbaik adalah FEM yang terdapat efek dalam perbedaan periode waktunya. Berdasarkan persamaan dengan FEM diasumsikan intercept yang dimiliki berbeda-beda yaitu dalam tahun 2014 hingga 2017.

\section{PEMBAHASAN}

Hasil dari penelitian, model terbaik didapatkan dari uji hausman yang membandingkan antara FEM dan REM. Model FEM terpilih karena memiliki nilai signifikan sebesar 0,0018. Pada pendekatan FEM akan terjadi intercept yang berbeda pada gabungan data potong lintang dan runtutan waktu dari persamaan regresi. Memasukkan variabel semu atau dummy variable 
ke dalam dua data tersebut akan terjadi perbedaan antar nilai parameter yang berbeda-beda. Perbedaan tersebut dapat diasumsikan bahwa terdapat intercept berbeda antar waktu namun intercept antar individu sama. Hal ini terjadi apabila slope sama antar individu dan waktu. Pada penelitian menunjukkan angka kejadian DBD mengalami kenaikan dan penurunan setiap tahunnya (2014 hingga 2017) yang artinya Intercept tersebut berbeda antar waktu. Hal demikian tepat dengan pemodelan fixed effect model.

Ketika model terbaik sudah ditentukan regresi panel langkah selanjutnya adalah pengujian asumsi regresi klasik. Pengujian asumsi klasik pada normalitas dan heteroskedasitas tidak terpenuhi, maka pelanggaran tersebut diatasi dengan menggunakan robust. Variabel yang berpengaruh terhadap kejadian DBD setelah penanganan menggunakan robust antara lain adalah kemiskinan, kepadatan penduduk dan curah hujan.

\section{Faktor yang Signifikan pada Kejadian DBD di Jawa Timur}

Faktor signifikan terhadap angka kejadian DBD berdasarkan analisis regresi panel adalah kemiskinan, kepadatan penduduk, dan curah hujan. Kemiskinan terhubung erat dengan daerah kumuh serta kekurangan pasokan air bersih (Nuryunarsih, 2015). Nilai koefisien dari kemiskinan dalam penelitian ini sebesar 20,7376 dengan probability 0,02 dapat diinterpretasikan peningkatan angka kemiskinan tiap satu satuan maka akan meningkatkan peluang jumlah kejadian DBD sebesar 20,73. Menurut Wowor (2017), kemiskinan merupakan faktor yang menyebabkan terjadinya kejadian DBD sebab orang miskin tidak mampu menyediakan rumah yang layak dan sehat dan kurangnya pemahaman tentang membuang sampah yang baik dan benar. Penelitian didukung oleh Dini, Fitriany dan Wulandari (2010) bahwa kondisi wilayah penelitian berada di bawah garis kemiskinan sehingga persoalan yang dihadapi adalah padat penghuni, kurangnya menjaga kebersihan dan banjir saat musim tertentu. Hal tersebut menunjang meningkatnya risiko penyakit menular khususnya DBD.
Salah satu penunjang penularan penyakit DBD adalah kepadatan penduduk. Apabila pada suatu daerah dengan jumlah penduduk meningkat, maka akan semakin mempermudah pula nyamuk menularkan virus ke penduduk yang lainnya. Jarak terbang Aedes aegypti maksimal 200 meter sehingga memudahkan penyebaran DBD ke daerah lainnya.

Melalui analisis statistik spasial ANN oleh Kusuma \& Sukendra (2016) menjelaskan bahwa pola penyebaran pada daerah kerja Puskesmas Kedungmundu dengan nilai $\mathrm{ANN}=0,52<1$ yang dapat disimpulkan kasus demam berdarah dengue memiliki pola penyebaran berkerumun dan jarak rata-rata antar kasus 90,30 meter sehingga area tersebut sebagai potensi terjadinya penularan DBD. Variabel kepadatan penduduk pada analisis yang dilakukan memiliki probability 0,001 dan koefisiensi sebesar 0,227604 diinterpretasikan sebagai peningkatan angka kepadatan penduduk tiap satu satuan maka akan meningkatkan peluang jumlah kejadian DBD sebesar 0,22. Penelitian ini juga didukung oleh Riyanto (2017) menunjukkan ada hubungan kasus DBD di Kabupaten Sleman bersamaan dengan padat penduduk dengan $p$ value sebesar 0,000 menggunakan uji korelasi Spearman.

Variabel yang signifikan lainnya adalah curah hujan. Curah hujan kaitannya dengan penyakit DBD adalah berkembangbiaknya nyamuk Aedes aegypti yang mempengaruhi tempat perindukan nyamuk. Tempat perindukan nyamuk Aedes aegypti akan hilang apabila curah hujan tinggi datang dan berlangsung dengan lama dan sebaliknya apabila terjadi curah hujan rendah dan lama dapat meningkatkan tempat perindukan nyamuk sehingga dapat meningkat pula populasi nyamuk. Koefisiensi curah hujan pada penelitian yaitu 0,040186 dan probability adalah 0,000. Angka tersebut dapat diinterpretasikan jika curah hujan mengalami naik dalam satu satuan sehingga dapat meningkatkan peluang sejumlah kejadian DBD sebesar 0,04. Sehingga dapat dinyatakan curah hujan berpengaruh dalam kejadian DBD.

Pada penelitian Iriani (2012) dengan menggunakan uji korelasi Spearman memiliki koefisien korelasi sebesar 0,353 serta $p=0,000$ menunjukkan ada korelasi kasus DBD anak yang dirawat dengan curah hujan. Namun, 
tidak hanya curah hujan yang berperan dalam perkembangbiakan nyamuk Aedes aegypti. Menurut Oktivani (2011) adanya air atau genangan merupakan tempat yang mendukung perkembangan nyamuk seperti pepohonan, ban bekas dan botol bekas yang berserakan. Selain itu perkembangbiakan dari telur hingga menjadi dewasa serta didukung oleh ketinggian suhu dan kelembaban udara.

\section{SIMPULAN DAN SARAN}

\section{Simpulan}

Simpulan yang didapatkan bahwa faktor yang signifikan terhadap kejadian DBD adalah kemiskinan, kepadatan penduduk dan curah hujan dengan model terbaik menggunakan regresi panel yaitu fixed effect model dengan perbedaan pada intercept waktu sehingga dapat ditunjukkan dengan perbedaan pada koefisien persamaan. Angka kejadian DBD di Jawa Timur memiliki naik turun pada tiap tahunnya yang artinya intercept berbeda antar waktu yaitu 2014 hingga 2017 namun sama antar individu yaitu kabupaten/kota.

\section{Saran}

Adapun beberapa masukan untuk Dinas Kesehatan Kabupaten/Kota di Jawa Timur adalah memberikan edukasi berupa sosialisasi masyarakat untuk lebih meningkatkan pemberantasan sarang nyamuk dengan 3M Plus seminggu sekali dan mengoptimalkan kader jumantik di setiap rumah terutama diawal musim hujan. Memberikan sosialisasi kepada masyarakat tentang penyediaan dan pemanfaatan sarana sanitasi (tempat sampah dan penyediaan air bersih) terutama wilayah yang memiliki persentase kemiskinan tinggi, serta memberikan sosialisasi tentang penggunaan kawat kasa pada jendela tiap masing-masing rumah dan untuk mencegah gigitan nyamuk setiap individu di dalam rumah dapat mengatasi dengan obat anti nyamuk.

\section{DAFTAR PUSTAKA}

Ang, K.T., Rohani, I., Look, C.H., 2010. Role of Primary Care Providers in Dengue Prevention and Control in the Community. Med $J$ Malaysia, 65(1), pp.58-62.

Dini, A.M.V., Fitriany, R.N., Wulandari, R.A., 2010. Faktor Iklim dan Angka Insiden Demam Berdarah Dengue di Kabupaten Serang. MAKARA, 14(1), pp.37-45.

Diputra, T.F., Sadik, K., Angraini, Y., 2012. Pemodelan Data Panel Spasial dengan Dimensi Ruang dan Waktu. Indonesian Journal of Statistics, 17(1), pp.6-14.

Gujarati, D.N., 2008. Basics Econometrics. 5th ed. New York: The McGraw-Hill.

Iriani, Y., 2012. Hubungan antara Curah Hujan dan Peningkatan Kasus Demam Berdarah Dengue Anak di Kota Palembang. Sari Poediatri, 13(6), pp.378-383.

Kusuma, A.P., Sukendra, D.M., 2016. Analisis Spasial Kejadian Demam Berdarah Dengue Berdasarkan Kepadatan Penduduk. Unnes Journal of Public Health, 5(1), pp.48-56.

Nuryunarsih, D., 2015. Sociodemographic Factors to Dengue Hemmorrhagic Fever Case in Indonesia. Jurnal Kesehatan Masyarakat Nasional, 10(1), pp.10-16.

Oktivani, M., 2011. Perbedaan Kepadatan Jentik Aedes Aegypti pada Daerah Endemis, Sporadis, dan Potensial DBD di Wilayah Kerja Puskesmas Demangan Kota Madiun. Skripsi. Universitas Airlangga.

Pangestika, M., Widodo, E., 2017. Analisis Regresi Panel terhadap Faktor-faktor yang Mempengaruhi Indeks Pembangunan Manusia di Kabupaten/Kota D.I Yogyakarta. Peran Profesi Akuntansi dalam Penanggulangan Korupsi, 8(2), pp.198-205.

Riyanto, S., 2017. Hubungan Kepadatan Penduduk dengan Kejadian Demam Berdarah Dengue di Kabupaten Sleman. Skripsi. Universitas Muhammadiyah Yogyakarta.

Sriyana, J., 2014. Metode Regresi Data Panel. Yogyakarta: EKONISIA.

Tairas, S., Posangi, G.D.K.J., 2015. Analisis Pelaksanaan Pengendalian Demam Berdarah Dengue Kabupaten Minahasa Utara. JIKMU, 5(1), pp.21-29.

Tomia, A., Hadi, U.K., Soviani, S., Retnani, E., 2016. Kejadian Demam Berdarah Dengue (DBD) Berdasarkan Faktor Iklim di Kota Ternate. JURNAL MKMI, 12(4), pp.241-249. 
Wowor, R., 2017. Pengaruh Kesehatan Lingkungan terhadap Perubahan Epidemiologi Demam Berdarah di Indonesia. Jurnal e-Clinic, 5(2), pp.105-113.
Yan, X., Su, X., 2009. Linear Regression Analysus: Theory and Computing. USA: World Scientific. 